\title{
Tax Return and Economic Growth: Evidence from Nigerian Experience (2000-2017)
}

\author{
Stephen I. Ocheni Ph.D, FCNA, FCTI. \\ Department of Accounting, Faculty of Management Sciences, Kogi State University, Nigeria \\ Friday Audu, Ph.D. \\ Department of Accounting, Kogi State University, Anyigba \\ Elaigwu Moses \\ Department of Accounting, Kogi State University, Anyigba
}

\begin{abstract}
This paper determined the effect of tax return on gross domestic product. Data were collected using secondary source only. The technique employed was multiple regressions as tool of analysis for the study. The findings of the study show that Tax Returns on Customs and Excise Duty, Value Added Tax and Aggregate Tax Revenue have positive significance growth rate on Gross Domestic Product. Based on this, the paper recommended among others that government should also ensure that they remove impediments to investment in form of legal and regulatory barriers. There is need to ensure stable macroeconomic environment. The Government should ensure that Value Added Tax Growth Rate is boosted in order to improve the economy.
\end{abstract}

Keywords:Tax return, Customs and Excise Duty (CED), Value Added Tax (VAT), Aggregated Tax revenue, Gross Domestic Product (GDP) and Nigerian tax

DOI: $10.7176 /$ RJFA/11-18-16

Publication date:September $30^{\text {th }} 2020$

\section{Introduction}

Government carries out functions for the good of the society. The primary aim of these function is to protect the basic rights of the citizens. To achieve these obligations, government generates income and resources using the tax system. Taxes are levied fees on individuals or corporate entities - either at the national, state, or local government levels - to finance government expenditures and responsibilities (Okpe, 2000; Kagan, 2020). Tax levied on the individual or corporate entities are generated basically from earnings like salary, payment made for goods and services, investment appreciations or capital gains, and dividends. In order words, tax payment is an economic term that refers to the transfer of income and resources from the private sector (the individual or corporate entity) to the public sector (government) and not merely for direct exchange of good or services. The transfer in tax payment is used to achieve the social and economic goals of a nation (Okpe, 2000). These income and resources according to Okpe (2000) and Onoh (2017) are required to maintain infrastructure as well as better the economy in terms of to generate employments, improve on the promotion of new industries and small-scale enterprises, increase growth of gross national products, create a stable market/price, promote free market economy, satisfy collective demands, favourable balance of payments position, equal distribution of resources/income, encourage priority sectors, promote labour and capital development, and encourage population development. Again, Jiang and Jiang (2014) asserts that the tax system is an important part of a country's economy.

The revolutionary change in the taxation system in India, Nigeria, and in many developing nations concentrates more in implementing reforms that reduces tax rates and exemptions (Purohit \& Purohit, 2010). For instance, in Nigeria in the early 1990s, sales tax was replaced with the Value Added Tax (VAT), while in Kenya, the VAT replaced stamps and other minor charges. The VAT represents only 5\% value for goods and services, except for items that are specifically excepted or zero-rated. In 2007, Nigerian government undertook various tax law reforms on petroleum profit tax, companies income tax, custom and excise duty and value added and others in order to improve its administration and also increase its yield so as to reduce the suffering of the masses because tax revenue is supposed to alleviate poverty. But in spite of these vital roles that the reform is expected to perform, there is however a great concern on the performance on the Nigeria tax return in relation to the Gross Domestic Product (GDP) which when viewed from the nature of activities taking place in the entire tax system look superficial. These may be as a result of improper tax administration, assessment and collection.

It is considerably true that tax system varies across countries, however, the objectives are basically the same (Odhiambo \& Olushola, 2018). However, most countries are bedevilled by the poor returns in tax payment. For instance, one-third of the instances for poor economic growth experienced in Nigeria over the years has been attributed to low-rates of personal and corporate income taxes (Ogbonna \& Odoemelam, 2015; Ojong, Ogar \& Oka, 2016). The over reliance on oil-generated revenue is very worrisome, considering the constant deflation in oil prices and a major rise in foreign currency. It therefore implied that other tax generating structures are either 
neglected or overlooked. According to Odusola (2006), about 70\% revenue are generated from oil; this by implication reveals that other traditional revenue for tax payment are either not accounted for or either neglected from government's management policy, coupled with incidences of lack of transparency and accountability. Again, the non-oil sector of tax return has readily lost its objectives. For instance, the custom excise duties originally aimed at discouraging the import and export of contraband goods is today been used as the money-bag of many top custom personnel and monies generated are hardly accounted for (Adegbie, 2011).

Again, the multiple account system operated by the Nigerian government in generating revenue has given rise to the economic challenge facing the country. However, the initial implementation of the single treasury account (TSA) in 2012 was aimed to curb corruption as well as unify the country's income and expenditures. Subsequently, this policy was greatly criticised overtime to drive a liquidity squeeze on the commercial businesses and negatively influence interest rates to rise (Okerekeoti \& Okoye, 2017; Adetula, Adegbenjo, Owolabi, Achugamonu \& Ojeka, nd). With the dwindling state of the economy, a whole lot of issues has been attributed to the poorly and misappropriate administration of the taxation system. As observed by Iweala (2013), many firms operating in Nigeria are not registered under the tax net of the country, while a whole more had not filed their tax returns for more than 2 years. Many studies over the years has established the relevance between tax returns and economic growth, however, these studies concentrated more on Value Added Taxes (Gatawa, Aliero \& Aishatu, 2016; Adegbie, Jayeoba \& Kwarbai, 2016; Awe, 2018). Arrayed with the possibilities that Tax return boosts economic growth, this study therefore examines the effect of tax return on economic growth in Nigeria (Tax report from 2000-2017). Specifically, the study aimed to establish the effect of customs and excise duty, value added tax, and aggregate tax revenue on the economic growth of Nigeria.

\section{Methodology}

The study is basically a time-series study and therefore adopts the Ex-Post Facto research design. It covers a timeseries of 18 years, from 2000-2017 because the study has to do with the effect of economic growth surrogate and the Tax revenue, in which case the contribution of all the components of economic growth in aggregate/yearly average is taken into consideration. Annual Abstract of Statistics and Journal articles was collected using the desk survey approach from reputable text books, journal articles, and government statistics/ bulletin. The aggregate tax revenue and its components were collected from the Federal Ministry of Finance between 2000 to 2017. The independent variables as depicted here are tax revenue generators are: custom and excise duty (CED), value added tax (VAT), and aggregated tax revenue (ATR).

Retrieved data were analyzed using basic statistical tool that will provide the descriptive analogies such as mean, median, standard deviation and the regression analogy of the findings. The study uses the Multiple Regression and Correlation Coefficient with the aid of SPSS version 21 Software, 2017 to analyse the data. The multiple regression was adopted because it is known to estimate how well the set of independent variables predicts the dependent variable, ascertain the relative contribution of the independent variables (VAT, CED, and ATR) in predicting the dependent variable (economic growth), determine the best subset of the predictor variable from the overall set and reveal the incremental validity of each predictor over every and is applied for robustness check. To determine the effects of Tax Revenue on economic growth in Nigeria, the researcher regressed the determinants of tax revenue such as custom and excise duty (CED), value added tax (VAT), and aggregated tax revenue (ATR) on economic growth (gross domestic products). The Multiple Regression statistical tools were used to analyze the data collected.

\section{Model Specification}

Model specification indicates the model mathematical or econometric which a research adopted. On the other side of the equation, the notation relating to tax revenue is expressed as follows:

$\mathrm{GDP}=\mathrm{f}(\mathrm{VAT}, \mathrm{PIT}$, and ATR 1

This function can also be better expressed as:

$\mathrm{GDP}=\mathrm{f}(\mathrm{VAT}+\mathrm{PIT}+\mathrm{ATR})$

Where, GDP is Gross Domestic Products in Nigeria.

However, the following model was employed in testing the hypotheses $1-3$

$\mathrm{GDP}=\beta 0+\beta \mathrm{CED} 1+\beta \mathrm{VAT} 2+\beta$ ATR $3+\mu \ldots .(1)$

Where:

VAT $=$ Value Added Tax

PIT $=$ Personal Income Tax

$\mathrm{GDP}=$ Gross Domestic Products

Aggregated tax revenue (ATR)

$\mathrm{CED}=$ Customs and Excise Duties

$\beta_{0:}=$ Constant Term (intercept)

$\beta 1=$ coefficient of CED 
$\beta_{2}=$ coefficient of VAT

$\beta_{3}=$ coefficient of ATR

$\mu$ : Error term

\section{Findings}

Decision Rule: Reject the null assumption if the p-value of the t-coefficient is less than $1 \%(0.01)$ or $5 \%(0.05)$, and if otherwise, accept it.

The following basis will also be employed in explaining the results:

i. Probability Value (P-Value): The level of significance between the independent variables (VAT, CED, and ART) and dependent variables were explained using the P-Value. The data were tested at 0.05 alpha value. This implied that where the P-Value is less than 0.05 , there exists a significant relationship. With this result, the alternate hypothesis will be retained while the null assumption(s) (hypothesis) will be rejected.

ii. $\boldsymbol{R} 2$ Adjusted: This is the coefficient of determination. It was applied in explaining the degree/percentage of the variations in the dependent variable, which explained/ caused by the changes in the explanatory variables. A high percentage indicates that the variation in the dependent variable attributed to independent variable is high while an inverse relationship exists when it is low.

iii. $\boldsymbol{F}$-Statistics: This defines the suitability of the analysis run.

Robustness Test: The following test were carried out to further scrutinize the results obtained as well as test for the validity of the results.

1. Autocorrelation test - Durbin Watson (D.W)

Table 1: Correlations

\begin{tabular}{llrrrr}
\hline & & LogGDP & LogCED & \multicolumn{1}{c}{ LogVAT } & \multicolumn{1}{c}{ LogATR } \\
\hline Pearson Correlation & LogGDP & 1.000 & .408 & .963 & .704 \\
& LogCED & .408 & 1.000 & .334 & .470 \\
& LogVAT & .963 & .334 & 1.000 & .782 \\
Sig. (1-tailed) & LogATR & .704 & .470 & .782 & 1.000 \\
& LogGDP &. & .058 & .000 & .001 \\
& LogCED & .058 &. & .103 & .033 \\
N & LogVAT & .000 & .103 &. & .000 \\
& LogATR & .001 & .033 & .000 &. \\
& LogGDP & $\mathbf{1 7}$ & $\mathbf{1 7}$ & $\mathbf{1 7}$ & $\mathbf{1 7}$ \\
& LogCED & $\mathbf{1 7}$ & $\mathbf{1 7}$ & $\mathbf{1 7}$ & $\mathbf{1 7}$ \\
& LogVAT & $\mathbf{1 7}$ & $\mathbf{1 7}$ & $\mathbf{1 7}$ & $\mathbf{1 7}$ \\
& LogATR & $\mathbf{1 7}$ & $\mathbf{1 7}$ & $\mathbf{1 7}$ & $\mathbf{1 7}$ \\
\hline
\end{tabular}

\section{Source: Regression Result using SPSS, 2018}

Table 1: shows a positive relationship between gross domestic product and customs and excise duties (.408), value added tax (.963) and total tax income (.704). This implies that tax returns are contributing significantly to the economic growth of Nigeria. This implied that the test result for VAT is positive and therefore highly significant to economic growth. As shown by the correlation matrix, the relationship between them is above fifty percent $(50 \%)$ with the exception of the correlation between customs and excise duties growth rate and GDP (0.408), VAT (0.334) and ATR (0.470) reaffirming the absence of multicollinearity.

Table 2 Coefficients a

\begin{tabular}{|c|c|c|c|c|c|c|c|}
\hline \multirow[b]{2}{*}{ Model } & \multicolumn{2}{|c|}{$\begin{array}{l}\text { Unstandardized } \\
\text { Coefficients }\end{array}$} & \multirow{2}{*}{$\begin{array}{c}\begin{array}{c}\text { Standardized } \\
\text { Coefficients }\end{array} \\
\text { Beta }\end{array}$} & \multirow[b]{2}{*}{$\mathrm{T}$} & \multirow[b]{2}{*}{ Sig. } & \multicolumn{2}{|c|}{$95.0 \%$ Confidence Interval for B } \\
\hline & $\mathrm{B}$ & Std. Error & & & & Lower Bound & Upper Bound \\
\hline $1 \quad$ (Constant) & 3.538 & 1.247 & & 2.758 & .020 & .660 & 6.217 \\
\hline $\log C E D$ & .177 & .118 & .183 & 1.495 & .007 & .000 & .000 \\
\hline LogVAT & .831 & .108 & .855 & 7.687 & .000 & .590 & 1.072 \\
\hline LogATR & .550 & .149 & .288 & 3.683 & .004 & .882 & .217 \\
\hline
\end{tabular}

Source: Regression Result using SPSS, 2018

The estimated relationship for the model is $\beta 0+\beta$ CED1 $+\beta$ VAT2 $+\beta$ ATR $3+\mu \ldots$. (1)

Substituting the model, GDP $=3.538+2.550(\mathrm{CED})+.831(\mathrm{VAT})+.550(\mathrm{ATR})$.

The above table indicates regression results on tax returns and economic growth in Nigeria. The model indicates that all the four proxy variables of tax returns (PPT, CED, VAT and ATR) have significant impact on the GDP at $0.020(\%), 0.007(7 \%), 0.000(0 \%)$ and $0.004(4 \%)$ alpha level while CIT is at $0.538 \%$, alpha level. This 
outcome therefore implies that higher tax returns incites economy growth of the country.

\section{Test of hypothesis one}

H01 : Customs and Excise Duty (CED) has no significant influence on economic growth in Nigeria.

Result of the regression table (Table 2) shows that the influence of CED as an explanatory variable significantly explains the variations in economic growth in terms of Gross Domestic Product in Nigeria. The implication of this revealed that an increase in CED will have significant influence on economic growth. Eventually, this will finally boost the revenue generation which will impact on Gross Domestic Product and overall economic development in the country. Furthermore, the result of CED at $0.7 \%(p$-value $=0.007)$ alpha level (put at 0.05$)$ is significantly relevant to Nigeria's gross domestic product. With this result, the null hypothesis is therefore rejected. Furthermore, as displayed on the table, a unit charge of the independent variable (tax returns) as explained by Customs and Excise Duty will yield to an increase of 0.177 in the gross domestic product. In line with the above equation, the influence of Customs and Excise Duty on Gross Domestic Product is positive.

Test of significance for custom and excise duty (CED)

Independent variable $=$ Customs and Excise Duty (CED)

Dependent variable $=$ Economic growth

Table value $\quad=p=0.007$

Unit Charge $\quad=0.177$

Significance level $=0.05(5 \%)$

Decision: The p-value X1=0.007 (CED) is less than $\alpha$-value of 0.05 . Therefore, we reject $\mathrm{H} 0$ and accept $\mathrm{H} 1$ for PPT as one of the explanatory variables.

Conclusion: The hypothesis tests the relationship between tax returns accruing from CED and GDP. The study shows a positive and significant relationship between Customs and Excise Duty (with p-value of $0.007(0.7 \%)$ is less than $\alpha$-value of $0.05(5 \%)$ and GDP in Nigeria. Therefore, H0 was rejected and H1 retained. We therefore conclude that Customs and Excise Duty (CED) has significant influence on Gross Domestic Product of Nigeria.

\section{Test of hypothesis two}

H0²: Value Added Tax (VAT) has no significant influence on the Gross Domestic Product of Nigeria.

Result of the regression analysis (Table 2) shows that the influence of VAT as an explanatory variable significantly explains the variations in economic growth. The implication of this revealed that an increase in VAT will have positive influence on Gross Domestic Product. Eventually, this will finally boost the revenue generation which will impact on the Gross Domestic Product in the country. Furthermore, the result of VAT at $0.00 \%$ ( $p$-value $=$ 0.000) alpha level (put at 0.05 ) is significantly relevant to Nigeria's gross domestic product. With this result, the null hypothesis is therefore rejected. Furthermore, as displayed on the table, a unit charge of the independent variable (tax returns) as explained by VAT will increase by 0.831 in the gross domestic product. In line with the above equation, the relationship between Value Added Tax and Gross Domestic Product is positive.

Test of significance for value added tax (VAT)

Independent variable $=$ Value Added Tax $(\mathrm{VAT})$

Dependent variable $=$ Economic growth

Table value $=p=0.000$

Unit charge $=0.831$

Significance level $=0.05(5 \%)$

Decision: The p-value X1=0.007 (CED) is less than $\alpha$-value of 0.05 . Therefore, we reject $\mathrm{H} 0$ and accept $\mathrm{H} 1$ for $\mathrm{PPT}$ as one of the explanatory variables.

Conclusion: The hypothesis tests the relationship between tax returns accruing from VAT and GDP. The study shows a positive and significant relationship between Value Added Tax (with p-value of $0.000(0.0 \%)$ is less than $\alpha$-value of $0.05(5 \%)$ and GDP in Nigeria. Therefore, $\mathrm{H} 0$ was rejected and $\mathrm{H} 1$ retained. We therefore conclude that there is significant influence of Value Added Tax on Gross Domestic Product of Nigeria.

\section{Test of hypothesis three}

$\mathbf{H 0}^{3}$ : The Aggregated Tax revenue has no significant contribution on economic growth in Nigeria.

Result of the regression analysis (Table 2) shows that the influence of aggregated tax revenue (ATR) as an explanatory variable significantly explains the variations in economic growth in Nigeria. This implies that an increase in ATR will have positive impact on economic growth. Eventually, this will finally boost the revenue generation which will impact on economic growth in terms of Gross Domestic Product in the country. Furthermore, the result of ATR at $0.4 \%$ (p-value $=0.004$ ) alpha level (put at 0.05 ) is significantly relevant to Nigeria's gross domestic product. With this result, the null hypothesis is therefore rejected. Furthermore, as displayed on the table, a unit charge of the independent variable (tax returns) as explained by aggregated tax revenue (ATR) will yield to an increase of 0.550 in the gross domestic product. In line with the above result, the relationship between 
aggregated tax revenue and Gross Domestic Product is positive.

\section{Test of significance for aggregated tax revenue (ATR)}

Independent variable $=$ Aggregated Tax Revenue (ATR)

Dependent variable $=$ Economic growth

Table value $=\mathrm{p}=0.004$

Unit charge $=0.550$

Significance level $=0.05(5 \%)$

Decision: The p-value X1=0.004 (CED) is less than $\alpha$-value of 0.05 . Therefore, we reject $\mathrm{H} 0$ and accept H1 for PPT as one of the explanatory variables.

Conclusion: The hypothesis tests the relationship between tax returns accruing from ATR and GDP. The study shows a positive and significant relationship between Aggregated Tax revenue (with p-value of $0.004(0.4 \%)$ less than $0.05(5 \%)$ and GDP in Nigeria. Therefore, $\mathrm{H} 0$ was rejected and $\mathrm{H} 1$ retained. We therefore conclude that there is significant contribution of Growth Rate of Aggregated Tax revenue on of Gross Domestic Product of Nigeria.

\section{Discussion of findings}

Hypothesis one analysed the significant influence of Customs and Excise Duty (CED) on Gross Domestic Product of Nigeria. The result arrived at showed that CED at $0.7 \%(p$-value $=0.007)$ alpha level (put at 0.05$)$ is significantly relevant to Nigeria's economic growth. Again, it was gathered that a unit charge of the independent variable (tax returns) as explained by Customs and Excise Duty will yield to an increase of 0.177 in the gross domestic product. This finding however corresponds with the result of Adegbie (2011) on his study on Customs and excise duties contribution towards economic growth of Nigeria and Yahaya and Yusuf (2019) on the study of the impact of nonoil tax revenue on economic growth in Nigeria. It was gathered that customs and excise duties positively influence Nigeria's economic growth. The implication from the study however proves that CED as an income source for the Nigerian government can improve the growth and development of the Nigerian economy. An examination on the impact of tax revenue on the economic growth in Nigeria over the period 1981-2007 (Okafor, 2012) showed a very positive and significant relationship. It further noted that although custom and excise duty is a significant factor in economic growth, it has been reportedly noted that it fell below the expected revenue generation level. This was largely attributed to a number of factors including infringement of tax laws, poor administration and dysfunctionalities. In line with this, Buba listed the following challenges for custom excise duties in Nigeria to include (i) presentation of fake and poorly arranged shipment manifestos (ii) poor collaboration among government agencies which thwarts efforts to deal effectively with increased trade flows. (iii) attitudes of officers, men of the service and major stakeholders to adjust to reforms. (iv) the high demand for foreign products. However, he proposed that the reforms should be successfully implemented that guarantee that all government revenue are retrieved, as a way of reimbursing the non-oil income in Nigeria.

Hypothesis two analysed the significant influence of Value Added Tax (VAT) on economic growth of Nigeria. The result arrived at showed that VAT at $0.00 \%(\mathrm{p}$-value $=0.000)$ alpha level (put at 0.05$)$ is significantly relevant to Nigeria's gross domestic product. Again, it was gather that a unit charge of the independent variable (tax returns) as explained by VAT will increase by 0.831 in the gross domestic product. This result agrees with Onwuchekwa and Aruwa (2014) on value added tax and economic growth in Nigeria. The study observed that an increase in VAT has a marginal positive impact on economic growth. Owolabi and Adejare (2018) empirically examined the effect of value added tax and economic growth in Nigeria between $1994-2010$. The outcome of the analysis showed that a $1 \%$ increase in VAT increases gross domestic product (economic growth) by $0.58 \%$ and increases exchange rate $(\mathrm{EXCH})$ by $3.39 \%$. this outcome was therefore significant and positively impact on economic growth and foreign earnings. Adereti, Adesina and Sanni (2011) carried out a time series study to examine the impact of value added tax revenue on economic growth of Nigeria during the period 1994 to 2008 and discovered a positive and significant correlation between VAT and economic growth. An examination on the contribution of Value Added Tax (VAT) to economic development of Lagos State (2001-2005) (Owolabi \& Okwu, 2011). It was revealed that revenue generated from VAT positively contributed to the economic development of Lagos State during the studied period.

Hypothesis three analysed the significant influence of aggregated tax revenue (ATR) on Nigeria's economic growth. The analysis showed that ATR at $0.4 \%(\mathrm{p}$-value $=0.004)$ alpha level (put at 0.05$)$ is significantly relevant to Nigeria's gross domestic product. Again, a unit charge of the independent variable (tax returns) as explained by aggregated tax revenue (ATR) will yield to an increase of 0.550 in the gross domestic product. This finding therefore attests that since economic choices are influenced by taxation, an aggregated tax revenue is therefore significant. This result is in agreement with the study in Ethiopia by Jalata (2014) on taxation for economic growth. From the study, it was positively tested that total taxable resources ratio $(8.1 \%)$ predicts about $91.8 \%$ positive variances for gross domestic product, and an average growth rate of $16 \%$ for TTR and $9.0 \%$ for GDP. Again, Edewusi and Ajayi (2019) conducted a time series study examining the nexus between tax revenue and economic growth in Nigeria. It was discovered that tax return has positive and noticeable effect on economic growth. 
growth

\section{Conclusion and recommendations}

It is an obligatory necessity for government to sustain the economic growth of any nation. Tax is therefore an eminent platform that boost government earnings and strengthen economic growth. It is therefore expedient that government utilises the tax system to meet its many obligations. This study therefore investigates the significant influence of tax returns on Nigeria's economic growth. It specifically examined the influence of custom and excise duty, value added tax, and aggregated tax revenue on economic growth in Nigeria. Data were sourced from the Nigeria tax statistics/ report between 2000-2017. The result of the analysis shows that Customs and Excise Duty has positive and significant relationship with the gross domestic of Nigeria. The implication of this outcome denotes that customs duties in the import and export of goods is a direct link at generating income for the country thereby boost their economic growth and impact. Also, an increase in Customs and Excise Duty will automatically improve the Gross Domestic Product of Nigeria. Again, the analysis result revealed that Value Added Tax has positive and significant relationship with the gross domestic of Nigeria. The implication to this result is that VAT will have direct impact at upgrading the Gross Domestic Product of the country if adequately coordinated. Furthermore, the result shows that Aggregated Tax revenue has positive and significant relationship with economic growth of Nigeria. This implies that Aggregated Tax revenue plays vital role in the economic growth of a nation because the improvement of the tax returns depends on the operating activities of the revenue generation and the more the number of quoted companies the better for the tax revenue as well as economic growth. This study therefore proposed the following recommendations:

- To improve on custom excise duty revenue, government income revenue policy should employ appropriate trade regulations that will advance foreign investments and propel international market for our local goods.

- To yield economic increase in Value Added Tax, government and non-government agencies should support and encourage business initiatives through investment in infrastructural development. This will increase aggregated tax return which invariably will improve economic growth.

- Tax avoidance should be discouraged through emulating the compliance measures of value added tax (VAT). Using a data base that captures income related activities.

\section{References}

Adegbie, F. F. (2011). Customs and excise duties contribution towards the development and growth of Nigerian economy. ResearchGate; Accessed online from https://www.researchgate.net/publication/291629036 Customs and excise duties contribution towards $\mathrm{t}$ he development_and_growth_of_Nigerian_economy\#read. Retrieved 22/08/2020

Adegbie, F., Jayeoba, J. O. \& Kwarbai, J. D. (2016). Assessment of value added tax on the growth and development of Nigeria economy: Imperative for reform (Nov 7, 2016). Accounting and Finance Research, 5(4), Available at SSRN: https://ssrn.com/abstract $=3024642$

Adereti, S. A., Adesina J. A. \& Sanni M. R. (2011). Value added tax and economic growth of Nigeria. European Journal of Humanities and Social Sciences, 10(1), 555-571.

Adetula, D., Adegbenjo, S., Owolabi, F., Achugamonu, U. \& Ojeka, S. (nd). Treasury single account policy and government revenue in Nigeria. Journal of Internet Banking and Commerce. Accessed online from http://www.icommercecentral.com/open-access/treasury-single-account-policy-and-government-revenuein-nigeria.php?aid=86008. Retrieved 27/8/2020.

Awe, E. (2018). Impact of value added tax on economic growth in Nigeria. Conference: management Science Conference, At Abuja, Nigeria

Buba, J. G. (2007). "The role of the customs reforms in boosting non-oil revenue in Nigeria". University of Jos, Nigeria Symposium 2007

Edewusi, D. G. \& Ajayi, I. E. (2019). The nexus between tax revenue and economic growth in Nigeria. International Journal of Applied Economics, Finance and Accounting, 4(2), 45-55. DOI: 10.33094/8.2017.2019.42.45.55.

Gatawa, N. M., Aliero, H. M. \& Aishatu, A. M. (2016). Evaluating the impact of value added tax on the economic growth of Nigeria. Journal of Accounting and Taxation, 8(6), 59-65.

Jalata, D. M. (2014). Taxation for economic growth: Evidence from Ethiopia. International Journal of Economics and Empirical Research (IJEER), The Economics and Social Development Organization (TESDO), 2(7), 294300.

Jiang, Y. F. \& Jiang, Y. F. (2014). The effect of VAT on total factor productivity in China-Based on the one-step estimation method. A Paper Presented at the International Conference on Management Science and Management Innovation. Accessed online fromhttp://ccsenet.org/journal/index.php/ijef/article/viewFile/37329/20892 on 21 April, 2016 
Kagan, J. (2020). Income tax terms guide: Taxes. Investopedia, Accessed online at https://www.investopedia.com/terms/t/taxes.asp. Retrieved 8/21/2020.

Odhiambo, O. \& Olushola, O. (2018). Taxation and economic growth in a resource-rich country: The case of Nigeria. Taxes and Taxation Trends, jolanta Iwin-Garzy?ska, IntechOpen, DOI: 10.5772/intechopen.74381. Available from: https://www.intechopen.com/books/taxes-and-taxation-trends/taxation-and-economicgrowth-in-a-resource-rich-country-the-case-of-nigeria.

Odusola, A. (2006). Tax policy reforms in Nigeria. Research Paper No. 2006/03 United Nations University. World Institute for Development Economic Research.

Ogbonna, G. \& Odoemelam, N. (2015). Impact of taxation on economic development of Nigeria: 2000-2013. Journal of Social and Policy Research Development, 9:251-267.

Ojong, C., Ogar, A. \& Oka, F. A. (2016). The impact of tax revenue on economic growth: Evidence from Nigeria. IOSR Journal of Economics and Finance (IOSR-JEF), e-ISSN: 2321-5933, p-ISSN: 2321-5925. 7(1), PP 3238. www.iosrjournals.org

Okafor, R. G. (2012). Tax revenue generation and Nigerian economic development. European Journal of Business and Management, 4(19): 49 - 56.

Okerekeoti, C. \& Okoye, E. I. (2017). Treasury Single Account (TSA) in Nigeria: A theoretical perspective (July 26, 2017). Chapter 38 in the proceedings of the 2017 International Conference on African Entrepreneurship and Innovation for Sustainable Development (AEISD), Available at SSRN: https://ssrn.com/abstract=3039329

Okpe, I. I. (2000). Personal income tax in Nigeria. Enugu: Ochumba Printing and Publishing Company.

Onoh, J. K. (2017). Dimensions of Nigerian monetary and fiscal policies-Domestic and external. Aba: Astria Meridian Publishers.

Onwuchekwa, J. C. \& Aruwa, S. A. S. (2014). Value added tax and economic growth in Nigeria. European Journal of Accounting Auditing and Finance Research, 2(8), 62-69.

Owolabi, A. U. \& Adejare, A. T. (2018). Value added tax and economic growth: the Nigeria experience (1994 2010). International Journal of Research in Commerce, IT \& Management, 2(3), 85-89.

Owolabi, S. A. \& Okwu, A. T. (2011). Empirical evaluation of contribution of value added tax to development of Lagos State economy. Middle Eastern Finance and Economics, 1(9): 24 -34.

Purohit, M. \& Purohit, V. (2010). Goods and services tax in India estimating revenue implications of the proposed GST, Foundation for Public Economics and Policy Research New Delhi-110052, A Study Sponsored by the Thirteenth Finance Commission.

Success, M. J., Success, E. B. \& Ifurueze, M. S. K. (2012). Impact of petroleum profit tax on economic development of Nigeria. British Journal of Economics and Management Sciences, 5(2), 60-70.

Yahaya, K. A. \& Yusuf, K. (2019). Impact of non-oil tax revenue on economic growth in Nigeria. Journal of Accounting and Management, 9(2), 56-69. 